\title{
Environmental gradient in reservoirs of the medium and low Tietê River: limnological differences through the habitat sequence
}

\author{
Gradiente ambiental em reservatórios do médio e baixo Rio Tietê:
} diferenças limnológicas ao longo da seqüência de habitats

\section{Welber Senteio Smith ${ }^{1,2}$, Evaldo Luis Gaeta Espíndola ${ }^{3}$ and Odete Rocha}

${ }^{1}$ Programa de Mestrado em Processos Tecnológicos e Ambientais, Universidade de Sorocaba - UNISO, Rodovia Raposo Tavares, km 92,5, CEP 18023-000, Sorocaba, SP, Brazil e-mail: welber_smith@uol.com.br

${ }^{2}$ Laboratório de Ecologia Estrutural e Funcional, Universidade Paulista, Av. Independência, 210, CEP: 18087-101, Sorocaba, SP, Brazil

${ }^{3}$ Centro de Recursos Hídricos e Ecologia Aplicada, Universidade de São Paulo - USP,

Av. Trabalhador São Carlense, CEP 13566-590, São Carlos, SP, Brazil

e-mail: elgaeta@sc.usp.br

${ }^{4}$ Departamento de Ecologia e Biologia Evolutiva, Universidade Federal de São Carlos -UFSCar, Rodovia Washington Luís, km 235 - SP 310 , CEP 13565-905, São Carlos, SP, Brazil

e-mail:doro@ufscar.br

\begin{abstract}
Aim: The reservoirs of the medium and low Tietê River are disposed as a "cascade series", in which time, physiographic features and influence from drainage basins present differences that determine variability in their dynamics. These reservoirs are submitted to different impacts from the urban centres which they drain, and also from agricultural activities. Considering these features, the aim of this work was to characterize the Medium and Low Tietê river stretches by limnological analysis (including water and sediments) considering dry and rainy seasons evaluating changes along the reservoirs sequence. Methods: Based on physical and chemical measurements on water and sediments from 16 points along the reservoirs and in the river mouth of the main tributaries, it was possible to make an environmental characterization of the study area. Results: This was performed focusing on water, sediment, habitat structure and time scale. Generally, the data showed a reduction in the values of the analyzed parameters along the reservoirs sequence. Moreover, it was possible to identify differences between the dry and rainy seasons for water and sediment parameters. Concerning habitat structure, there is a gradient along the river, which shows that the environmental quality improves from the river head to the river mouth. Differences in macrophyte composition, kind of sediments, transparency and habitats were also identified. Conclusions: Therefore, modifications were identified in the habitats general structure along the medium Tietê stretch: emerging macrophytes and muddy bottom predominate upstream; and submerging macrophytes and sandy bottom predominate downstream. The water characteristics should be taken into consideration, because they reflect the impacts upon the drainage basin of each reservoir.
\end{abstract}

Keywords: Tietê River, damming, limnology, cascade effect, habitat structure.

Resumo: Objetivo: Os reservatórios do médio e baixo Tietê compóem uma série em "cascata" cujas idades, características fisiográficas e influencia da bacia de drenagem apresentam diferenças determinando diferenças nas suas dinâmicas. Tais reservatórios são submetidos a diferentes impactos pelos centros urbanos as quais drenam e também pela atividade agrícola. Considerando essas características, este trabalho teve como objetivo caracterizar o médio e baixo Tietê através da análise limnológica (água e sedimento), considerando as épocas seca e chuvosa avaliando mudanças ao ao longo da sequência de reservatórios. Métodos: Com base em amostragens físicas e químicas da água e sedimento em 16 pontos ao longo dos reservatórios e na foz dos principais tributários foi possível realizar uma caracterizaçáo ambiental da área de estudo focando a água, o sedimento, a estrutura de habitats e a escala temporal. Resultados: Os resultados mostraram de forma geral redução dos valores dos parâmetros analisados ao longo da seqüência de reservatórios. Além disso, foi possível identificar diferenças entre as épocas seca e chuvosa tanto para os parâmetros da água como de sedimento. Com relação a estrutura de hábitats há um gradiente ao longo do rio mostrando melhora na qualidade ambiental no sentido montante-jusante e também diferenças na composição das macrófitas, tipo de sedimento, 
transparência e habitats.Conclusóes: Foram identificadas modificações na estrutura geral dos habitats ao longo do trecho médio Tietê: macrófitas emergentes e fundo lodoso predominam a montante enquanto macrófitas submersas e fundo arenoso predominam a jusante. As características da água deve ser levado em consideração, porque eles refletem os impactos sobre a bacia de drenagem de cada reservatório.

Palavras-chave: Tietê, represamento, limnologia, efeito cascata, estrutura do habitat.

\section{Introduction}

The most extensive period of dam construction was concentrated in 20th century (Mallik and Richardson, 2009; Li et al., 2012). Almost 60\% of large river systems were affected by dams (Nilsson et al., 2005; Li et al., 2012). Large reservoirs are distributed all over the Brazil, but theis number is particularly high in the Southheast region (Nogueira et al., 2010). A number of studies have demonstrated that the river can be remarkably impacted by damming, leading to habitat heterogeneity, declines in species richness and native species and exotic species invasion (Tealdi et al., 2011; Li et al., 2012). The changes in ecological processes associated with dam construction in both aquatic and terrestrial riparian ecosystems have become a key focus of river studies (Gordon and Meentemeyer, 2006).

In case of reservoir cascades, just a few efforts have been undertake, to declines how their functioning affect the river ecological structure and functioning (Barbosa et al., 1999; Nogueira et al., 2010). It is necessary to learn the accumulated effect of cascade dams on hydrological characteristics, sediment and nutrient pollution discharge (Ouyang et al., 2011).

Many reservoirs built into rivers follow a cascade configuration, which means that two or more reservoirs are distributed along the watercourses. Cascading hydropower dams, defined as a series of dams from upstream to downstream (Fang and Deng, 2011)

The construction of reservoirs in sequence impliesan interruption of the nature of water with typical behavior of river. However, the impact of modifying a river to a series of tanks have produced changes in the water system that are not yet fullyknown. Depending on the distance between the dams along the river, building a reservoir cascade systems has the potential to enhance the effects of damming the river in the biological composition anddistribution (Callisto et al., 2005).

A pionner survey of a series of connected reservoirs in Brazil, with a limnological integrated river basin aproach, was carried out in the Tietê River, state of São Paulo by Tundisi et al. (1991).
Detailed investigations of the influence of Brazilian reservoir cascades on the biota aquatic and limnological factors are still scarce (Nogueira et al., 2010).

In reservoirs cascades the alterations in water quality as well as in the biotic composition and distribution are the results of modifications in the lateral, vertical and longitudinal dimensions, as descrited in the Cascading Reservoir Continnum Concept (CRCC) (Barbosa et al., 1999).

Studies along 8 reservoirs in the Tietê river; 5 reservoirs in the Iguaçu river, 3 reservoirs in the lower São Francisco river showed that phytoplankton, periphyton, macroinvertebrates, macrophyts and fish are highly affected by hydrodynamic changes (Padisák et al., 2000; Cavenaghi et al., 2003; Smith, 2004; Silva et al., 2005; Felisberto and Rodrigues, 2005; Callisto et al., 2005; Patesse et al., 2007; Jorcin and Nogueira, 2008).

The Tietê River, along its course, encounters various impacts such as pollution, damming and loss of riparian vegetation. In it's medium and low stretches there are reservoirs created by damming, mainly for electrical energy generation. The dams of the medium and low Tietê River were built between the 1950s and 1990s. The first reservoir to be constructed was Barra Bonita (1964), followed by Bariri (1969), and Ibitinga (1969) reservoirs. The Promissão reservoir was constructed in 1975, the Nova Avanhandava in 1985, and the Três Irmãos in 1991 (Barbosa et al., 1999).

The damming of the river lead to changes in the lotic system (river), turning it to a lentic system (lake), which favors the creation of three different zones: the river zone, at the head, with faster flow and more intense processes in the horizontal axis; the transition zone, intermediary between the river and the lake; and the lacustrine zone, next to the dam, with slower flow and prevalence of processes in the vertical axis. According to Cooke et al. (1993), the river zone has a faster water flow and high concentration of suspended solids and nutrients; the transition zone has a slower flow, low concentration of suspended solids and nutrients, and high levels of photosynthesis; the lacustrine zone shows very 
clear water, the lowest flow and concentration of suspended solids and nutrients.

In the Tietê system, the reservoirs are arranged as a cascade series, which reduces the river and the transition zones. Along the reservoirs sequence, changes in the system occur, such as reduction in turbidity, increase in transparency and alterations in biota composition (Barbosa et al., 1999). The cascade system improves the water quality, since part of the nutrients and pollutants are detained in the preceding reservoirs (Straškraba, 1994). In this way, the reservoir position is an important factor to be analyzed, associated with the unloading effect of the previous reservoir (Straškraba, 1994; Tundisi, 1996, 1999a).

The hydrodynamic of this complex system is also influenced by the tributaries, and by the floodgate opening and closing operational mechanisms, with great fluctuation on the water level, on the flow, and on the residential time. Other factors that also influence the hydrodynamic are the solar radiation, pluviometric precipitation, and wind, characterizing the majority of the reservoirs as polymitic (Barbosa et al., 1999).

Associated with this important system, which configures a great impact on the natural conditions of the river, there is also the intense loss of the riparian forest due to urban and rural expansion, as well as the discharge of pollutants from the cities placed on it's bank and through it's tributaries such as the Piracicaba and Jaú rivers, among others. The main causes of degradation of the water quality are the punctual pollution sources (sewage and industrial effluents) and diffuse sources (urban and agricultural drainage), besides atmospheric precipitation (Lloyd, 1992). Considering these features, the aim of this work was to characterize the Medium and Low Tietê river stretches by limnological analysis (including water and sediments) considering dry and rainy seasons evaluating changes along the reservoirs sequence.

\section{Material and Methods}

\subsection{Study area}

The study area covers the Medium and Low Tietê River stretches, including sampling stations placed upstream from the beginning of the reservoirs cascade, six reservoirs and six tributaries (Figure 1). For water and sediment physical and chemical characterization, 8 sampling stations were selected (lacustrine zone); whereas for habitat description 16 stations were sampled (transitional and lacustrine zone) (Table 1). Riverine zone were not sampled because due to position of reservoirs in the cascade, the area is not present in most reservoirs reviews. Sampling events took place in July, 2000 (dry period), and January, 2001 (rainy period).

\subsection{Sampling data}

To characterize the sampling stations, physical and chemical variables were measured in the

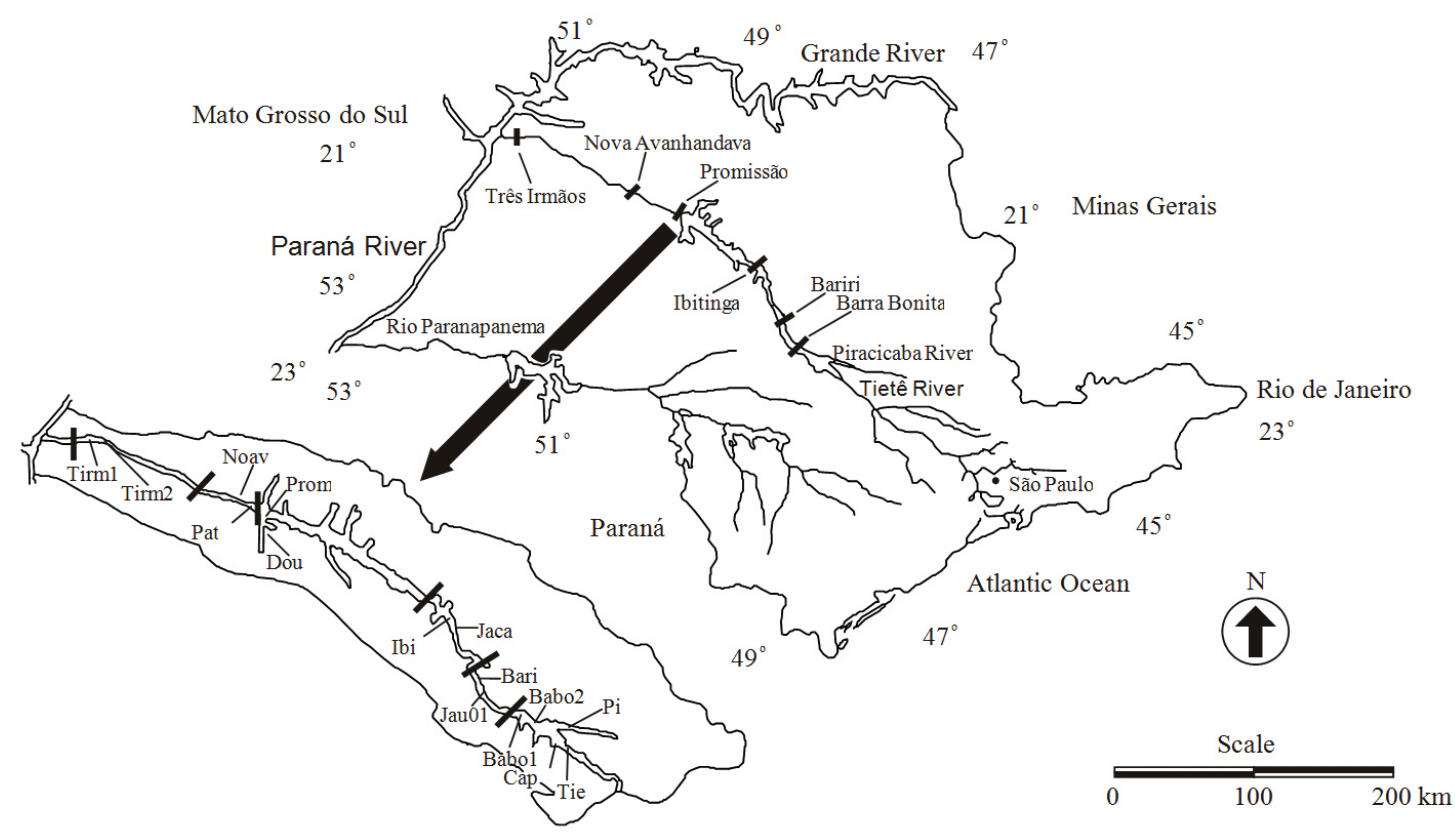

Figure 1. Location of the reservoirs, main tributaries and distribution of the sampling stations in the Tietê River, SP. 
Table 1. Code, site, zone and geographic location of the sampling stations. ${ }^{*}$ Sampling stations where water and sediment physical and chemical variables were analyzed.

\begin{tabular}{|c|c|c|c|c|}
\hline \multirow{2}{*}{ Code } & \multirow{2}{*}{ Site } & \multicolumn{3}{|c|}{ Geographic location } \\
\hline & & Zone & South & East \\
\hline tie & Tietê River & transitional & $22^{\circ} 39^{\prime} 54.4^{\prime \prime}$ & $48^{\circ} 9^{\prime} 03.4^{\prime \prime}$ \\
\hline cap & Capivara River, Tietê's tributary & transitional & $22^{\circ} 42^{\prime} 40.8$ & $48^{\circ} 22^{\prime} 17^{\prime \prime}$ \\
\hline pir॰ & Piracicaba River & transitional & $22^{\circ} 38^{\prime} 27.1^{\prime \prime}$ & $48^{\circ} 09^{\prime} 51^{\prime \prime}$ \\
\hline babo• & Barra Bonita Reservoir & lacustrine & $22^{\circ} 31^{\prime} 56.2^{\prime \prime}$ & $48^{\circ} 31^{\prime} 05.4^{\prime \prime}$ \\
\hline bari॰ & Bariri Reservoir & lacustrine & $22^{\circ} 09^{\prime} 51.5^{\prime \prime}$ & $48^{\circ} 45^{\prime} 36^{\prime \prime}$ \\
\hline jau & Jaú River & transitional & $22^{\circ} 11^{\prime} 45.5^{\prime \prime}$ & $48^{\circ} 40^{\prime} 24.6^{\prime \prime}$ \\
\hline $\mathrm{ibi}^{\bullet}$ & Ibitinga Reservoir & lacustrine & $21^{\circ} 52^{\prime} 12.7^{\prime \prime}$ & $48^{\circ} 59^{\prime} 05.9^{\prime \prime}$ \\
\hline jaca & Jacaré-Guaçu River & transitional & $21^{\circ} 49^{\prime} 58^{\prime \prime}$ & $48^{\circ} 54^{\prime} 05.9^{\prime \prime}$ \\
\hline iac & lacanga River & transitional & $21^{\circ} 52^{\prime} 12.7^{\prime \prime}$ & $48^{\circ} 59^{\prime} 05.9$ \\
\hline prom• & Promissão Reservoir & lacustrine & $21^{\circ} 24^{\prime} 12.6$ & $49^{\circ} 42^{\prime} 19.3^{\prime \prime}$ \\
\hline dou & Dourado River & transitional & $21^{\circ} 24^{\prime} 12.6^{\prime \prime}$ & $49^{\circ} 42^{\prime} 13.3^{\prime \prime}$ \\
\hline noav• & Nova Avanhandava Reservoir & lacustrine & $21^{\circ} 15^{\prime} 43.2^{\prime \prime}$ & $49^{\circ} 51^{\prime} 06.8^{\prime \prime}$ \\
\hline pat & Dos Patos River & transitional & $21^{\circ} 17^{\prime} 15.8^{\prime \prime}$ & $49^{\circ} 50^{\prime} 29.2^{\prime \prime}$ \\
\hline tirm ${ }^{\circ}$ & Três Irmãos Reservoir & lacustrine & $20^{\circ} 40^{\prime} 25.2^{\prime \prime}$ & $51^{\circ} 30^{\prime} 06.8^{\prime \prime}$ \\
\hline $\cot$ & Do Cotovelo River & transitional & $20^{\circ} 48^{\prime} 24.5^{\prime \prime}$ & $51^{\circ} 04^{\prime} 52,8^{\prime \prime}$ \\
\hline ita & Tietê River & transitional & $20^{\circ} 39^{\prime} 18.8^{\prime \prime}$ & $51^{\circ} 29^{\prime} 25.8^{\prime \prime}$ \\
\hline
\end{tabular}

- Sampling stations where water and sediment physical and chemical variables were analyzed.

water, and some of these variables were related to each sampling station habitat structure. A single vertically integrated sample of water was collected with a suction pump from each sampling station. Temperature, $\mathrm{pH}$, conductivity and dissolved oxygen were measured at $0.5 \mathrm{~m}$ depth using a Horiba U-10. Water samples were transferred to previously washed and dried plastic bottles and stored at $4{ }^{\circ} \mathrm{C}$ until the moment they were analyzed. Total organic nitrogen (Golterman et al., 1978), total phosphorous (APHA, 1995), total dissolved phosphate (Golterman et al., 1978), inorganic phosphate (Golterman et al., 1978), ammonia (Koroleff, 1976), nitrite and nitrate (Mackereth et al., 1978), chlorophyll (Nush, 1980), total lift material, inorganic and organic lift material (Fonseca, 1997), reactive silicate (Golterman et al., 1978), suspended material (Teixeira et al., 1978), total cadmium, chromium, copper and zinc (APHA, 1995) were analyzed.

Sediment samples were collected with an Eckman dredge and immediately stored in plastic containers inside styrofoam boxes containing ice until their analysis in the laboratory. Analyses of organic matter (Fonseca, 1997), granulometry (ABNT, 1968) and concentration of potentially bioavailable metals $(\mathrm{Cd}, \mathrm{Cr}, \mathrm{Cu}$ and $\mathrm{Zn}$ ) (Tessier and Campbell, 1987) were made.

The variables kind of substrate and submerged structures were obtained using an echobathymeter Garmin (GPSMAP 135 model, besides direct observation), depth (measured in meters using a graduated line), flow (obtained from the Companhia Paulista de Força e Luz (Power and Light São Paulo Company, Brazil), average resistance time (calculated from the monthly operational average volume, by the monthly effluent average flow), transparency (Secchi disk, with diameter of $30 \mathrm{~cm}$ ), presence or absence of submerged structures (trunks, rocks, etc.) and aquatic macrophytes (Platts et al., 1987). Marginal vegetation and sediment were evaluated using the following characterization: 0 (absence), 0.5 (presence in $50 \%$ of the area) and 1 (present in $100 \%$ of the area).

\subsection{Data analysis}

Data were evaluated through multivariate techniques. These techniques have been used to simplify data structure in ecological studies, by means of transformations, sampling classification, groups of individuals or variables, analysis of interdependency, and assistance in formulation of tests of hypothesis.

Principal Components Analysis was used to analyze the data. This is an ordination technique which aims to arrange samples in a lower number of dimensions by: keeping an essential percentage of information; getting rid of "noise"; emphasizing the greater variation patterns; and producing maximum information about the patterns and ecological similarities (Digby and Kempton, 1987). In this study, the correlation matrix was used.

The best results are obtained when the original variables are highly correlated (Manly, 1986). In this 
work, the aim of this analysis was to help generating hypotheses (Digby and Kempton, 1987) with environmental data from each sampling station.

\section{Results}

\subsection{Water physical and chemical characterization}

Table 2 presents data for physical and chemical variables measured in water. There is a decrease in values from the first (Barra Bonita) to the last reservoir (Três Irmãos) of the cascade system, except for silicates (closest values). It was also verified that the values were generally higher for the sampling stations located before the cascade system, as well as for the first three reservoirs, than for the ones at the low course of the river. Besides, there were differences between results obtained in the dry and rainy seasons. In the dry season, higher values for conductivity and transparency were found, as well as higher nitrate and total organic nitrogen concentrations were detected. On the other hand, in the rainy season, higher concentrations of nitrite, total phosphorus, total dissolved phosphorus, inorganic phosphorus and suspended materials (considering both organic and inorganic fractions) were obtained. Considering dissolved oxygen, the greater concentrations occurred in the rainy season, in the upper stretches of the cascade system; they were, however, higher both in dry and rainy seasons in the sampling stations placed after Ibitinga reservoir.

Concerning metals, the values obtained for iron, manganese, magnesium, and zinc were greater in the rainy season; whilst the greatest lead concentrations occurred in the dry season. Generally, a reduction on metal concentration in water in the longitudinal axis of Tietê River was found, which shows the cascade effect in the sequence of reservoirs. The water quality improves from the first (Barra Bonita) to the last reservoir (Três Irmãos) of the system (Table 2).

\subsection{Sediment physical and chemical characterization}

Table 3 presents physical and chemical variables measured in sediment samples and the differences between dry and rainy seasons. The highest percentage contribution of organic material and nitrogen and total phosphorus concentrations were obtained for the first reservoirs, with a reduction in values along the cascade of reservoirs. Concerning sediment granulometry, there was a higher contribution of clay and sand fractions in Medium and Lower stretches of Tietê River, respectively. For metals, the higher concentrations were found in the dry season. Chrome was an exception with higher values in the rainy season. Similar to the water compartment, there was found a decrease in metal concentration in the sediment along the sequence of reservoirs, again pointing to a cascade effect. The quality of both water and sediments improves from the first (Barra Bonita) to the last reservoir (Três Irmãos) of the system.

\subsection{Classification of the sampling stations}

With the data obtained for water and sediment physical and chemical variables, a Principal Component Analysis was performed. Only the first two components were considered since they together explained $56.48 \%$ of the total variance (Table 4).

The first principal component was responsible for $38.96 \%$ of the total variance. The main variables that contributed to form this axis were: conductivity, nitrite, ammonia, total dissolved phosphorus, inorganic phosphorus, chlorophyll, inorganic suspended materials, manganese, phosphorus in the sediments, organic materials in the sediments, thick sand, medium sand, clay and metals in the sediments (all with positive values), and dissolved oxygen, water transparency, lead and cadmium in water, inorganic materials in the sediments and fine sand (all with negative values). This component can be interpreted as the location of the sampling stations along the cascade of reservoirs.

The second principal component represented $17.52 \%$ of the variance. The more representative variables were: conductivity, nitrate, total nitrogen, and medium sand (all with positive values), temperature, dissolved oxygen, total suspended materials, iron, magnesium and zinc in water, and chrome in the sediments (all with negative values). This principal component was interpreted as the seasonal variation, that is, the differentiation between dry and rainy seasons.

Figure 2 shows the sampling stations arranged according to their scores in a continuous way. On the right side of the graphic are placed the upstream stations, which present, generally, higher values of conductivity, hardness, nitrite, ammonia, phosphate, and chlorophyll, and lower values of dissolved oxygen and water transparency, suggesting that these sites received a heavy load of effluents from diffuse and punctual pollution. On the left side of the graphic are placed the stations towards to the river mouth, which have lower values of conductivity, hardness, nitrite, ammonia, 


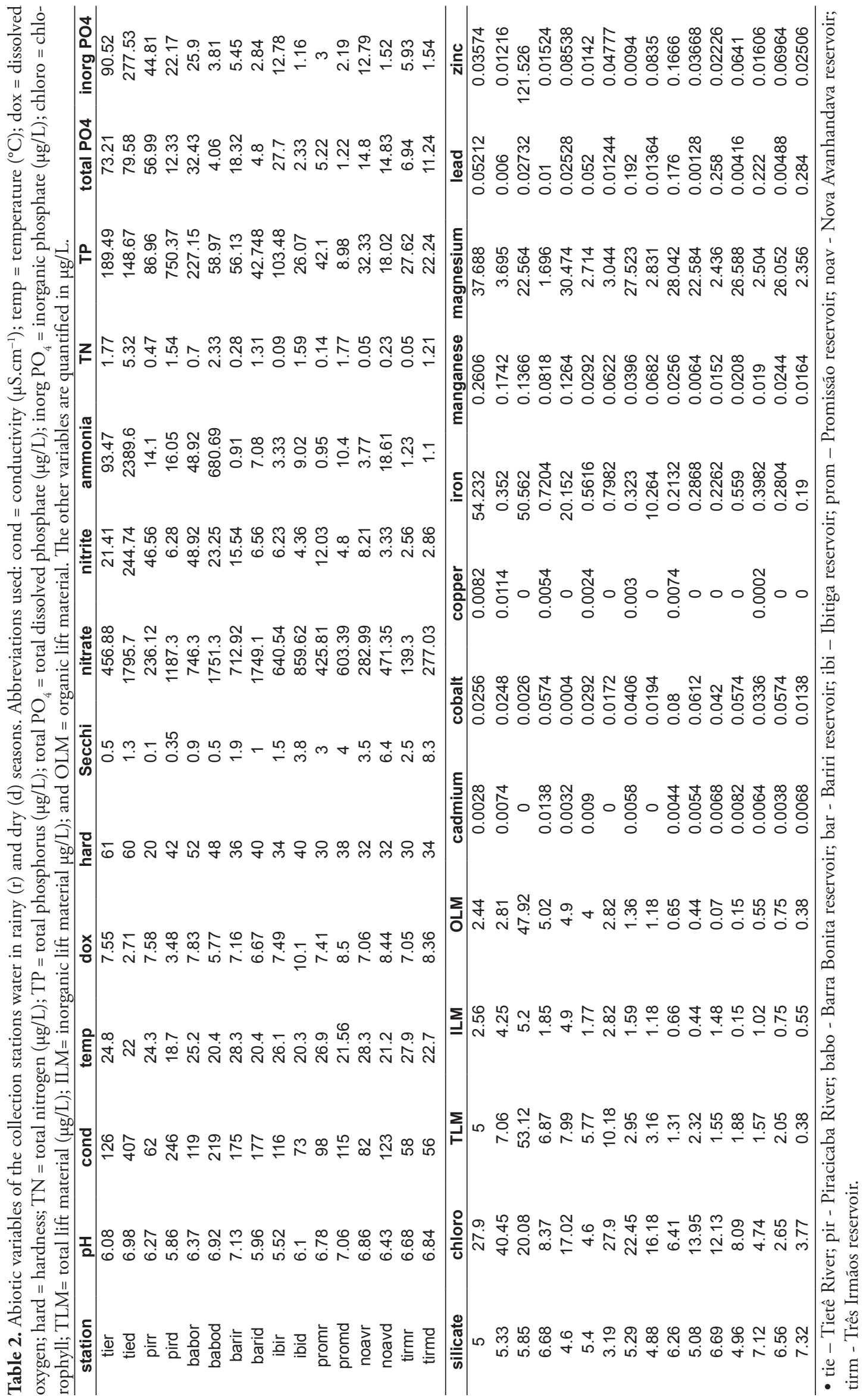




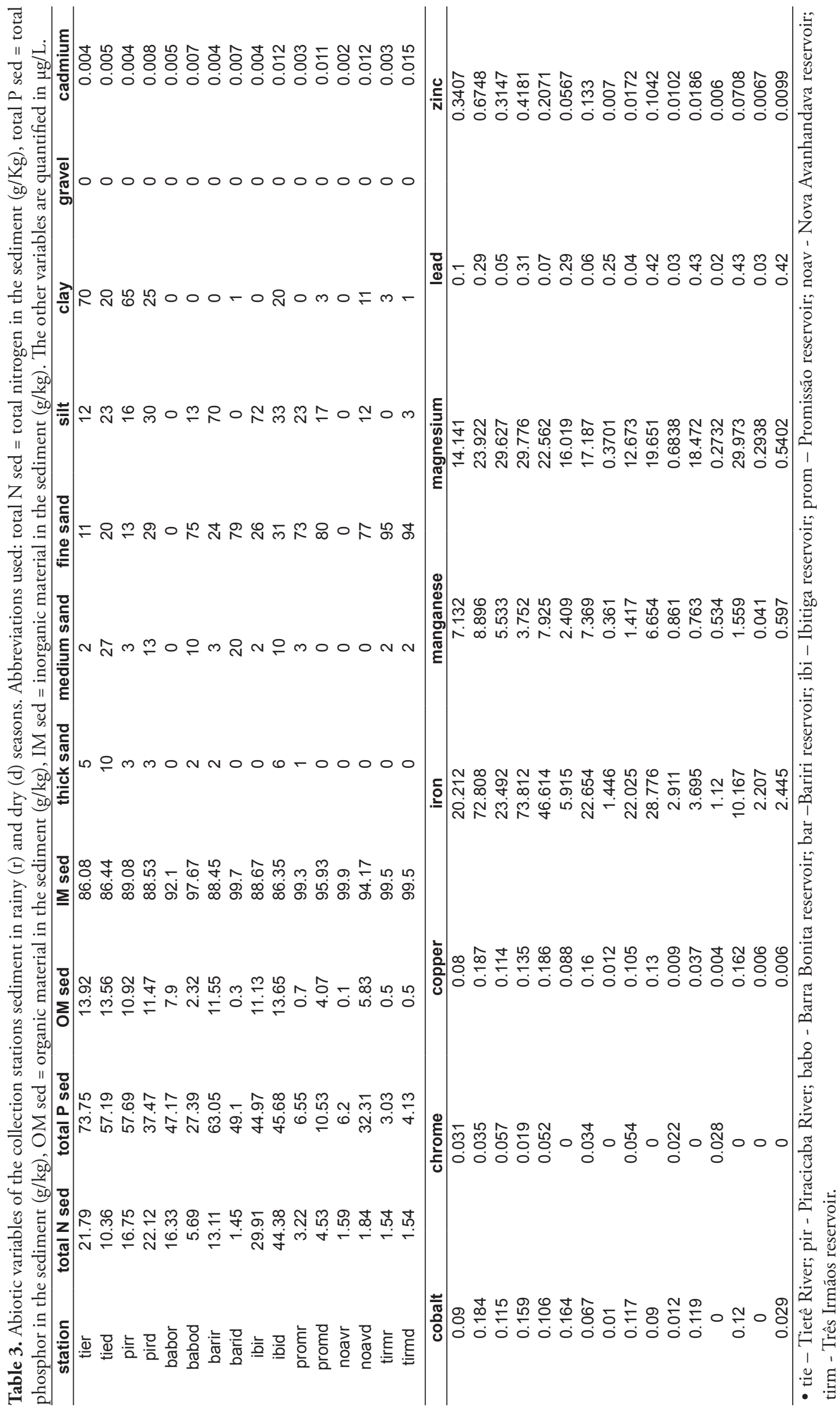


Table 4. Results from the Principal Component Analysis: values obtained for the abiotic variables of each principal component with the two greater percentages of variance.

\begin{tabular}{|c|c|c|}
\hline Abiotic variables & PC1 & PC2 \\
\hline $\mathrm{pH}$ & -0.238 & 0.278 \\
\hline Conductivity & 0.675 & 0.630 \\
\hline Temperature & -0.105 & -0.654 \\
\hline Dissolved oxygen & -0.562 & -0.431 \\
\hline Hardness & 0.581 & 0.454 \\
\hline Water transparency (Secchi) & -0.687 & 0.263 \\
\hline Nitrate & 0.445 & 0.637 \\
\hline Nitrite & 0.722 & 0.399 \\
\hline Ammonia & 0.608 & 0.594 \\
\hline Total organic nitrogen (water) & 0.564 & 0.727 \\
\hline Total phosphorus (water) & 0.458 & 0.121 \\
\hline $\begin{array}{l}\text { Total dissolved phosphorus } \\
\text { (water) }\end{array}$ & 0.823 & -0.155 \\
\hline Inorganic phosphorus (water) & 0.765 & 0.357 \\
\hline Silicate & -0.447 & 0.366 \\
\hline Chlorophyll & 0.785 & -0.012 \\
\hline Total suspended materials & 0.449 & -0.558 \\
\hline Inorganic suspended materials & 0.804 & -0.222 \\
\hline Organic suspended materials & 0.379 & -0.550 \\
\hline Cobalt (water) & -0.285 & 0.218 \\
\hline Iron (water) & 0.494 & -0.654 \\
\hline Manganese (water) & -0.840 & -0.201 \\
\hline Magnesium (water) & 0.090 & -0.530 \\
\hline Lead (water) & -0.549 & 0.373 \\
\hline Zinc (water) & 0.286 & -0.615 \\
\hline Total nitrogen (sediment) & 0.497 & -0.201 \\
\hline Total phosphorus (sediment) & 0.831 & -0.185 \\
\hline Organic materials (sediment) & 0.840 & -0.103 \\
\hline Inorganic materials (sediment) & -0.839 & 0.104 \\
\hline Thick sand & 0.786 & 0.322 \\
\hline Medium sand & 0.501 & 0.634 \\
\hline Fine sand & -0.731 & 0.405 \\
\hline Silt & 0.319 & -0.124 \\
\hline Clay & 0.590 & -0.366 \\
\hline Cadmium (sediment) & -0.417 & 0.502 \\
\hline Cobalt (sediment) & 0.695 & 0.330 \\
\hline Chrome (sediment) & 0.655 & -0.584 \\
\hline Copper (sediment) & 0.759 & 0.074 \\
\hline Iron (sediment) & 0.816 & 0.258 \\
\hline Manganese (sediment) & 0.865 & -0.057 \\
\hline Magnesium (sediment) & 0.668 & 0.033 \\
\hline Lead (sediment) & -0.224 & 0.732 \\
\hline Zinc (sediment) & 0.912 & 0.211 \\
\hline Percentage of variance by factor & $38.96 \%$ & $17.52 \%$ \\
\hline Accumulated variance & & $56,48 \%$ \\
\hline
\end{tabular}

phosphate, and chlorophyll, and higher values of dissolved oxygen and water transparency, and thus present better conditions than the upstream stations.

When Figure 2 is analyzed considering factor 2, the separation of the stations in two seasons, dry (upper part) and rainy (lower part) can be observed.

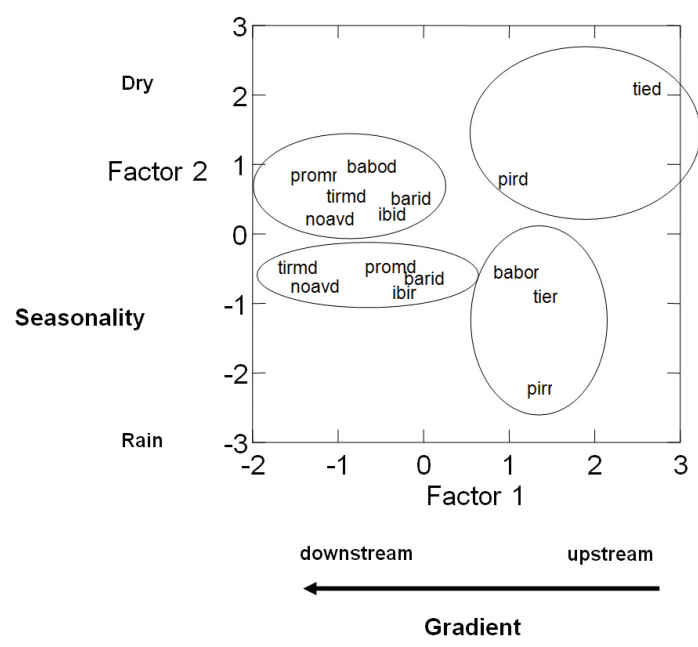

Figure 2. Representative diagram of the environmental analysis of the sampling stations located in Medium and Low Tietê River considering factor 1 (longitudinal gradient - cascade effect) and factor 2 (seasonal variation - dry and rainy seasons).

In the dry period, the values of conductivity, nitrate, and total nitrogen (in water), and medium sand, ammonia, cadmium, and lead (in the sediments ) are higher, and the temperature, dissolved oxygen, total suspended materials, organic suspended materials, iron, magnesium, zinc, and chrome (in the sediments) are lower. The opposite occurs in the rainy season.

\subsection{Characterization of the habitats}

Table 5 depicts values for the abiotic variables related to habitat characterization for each sampling station in both dry and rainy seasons. From the data analysis, a gradient was verified along the Medium and Low Tietê River stretches. In the sampling stations located in the first reservoirs and tributaries, such as Tietê River (tie01), Barra Bonita (babo01), Piracicaba River (pira01), Bariri (bari01), and Jaú River (jau01), there higher values were obtained for conductivity, reduced water transparency, low concentration of dissolved oxygen and more acid $\mathrm{pH}$. The bottom was muddy with great abundance of floating macrophytes, such as Eichhornia sp. and Salvinia sp.

In the sampling stations downstream of Ibitinga reservoir, such as Promissão (prom01), Nova Avanhandava (noav01), Três Irmãos (tirm01), and Itapura (ita01), there were the lowest values for conductivity, greater water transparency, higher concentration of dissolved oxygen and more neutral or basic $\mathrm{pH}$. The bottom was sandy, with large occurrence of trunks, and higher abundance of submerged macrophytes. 


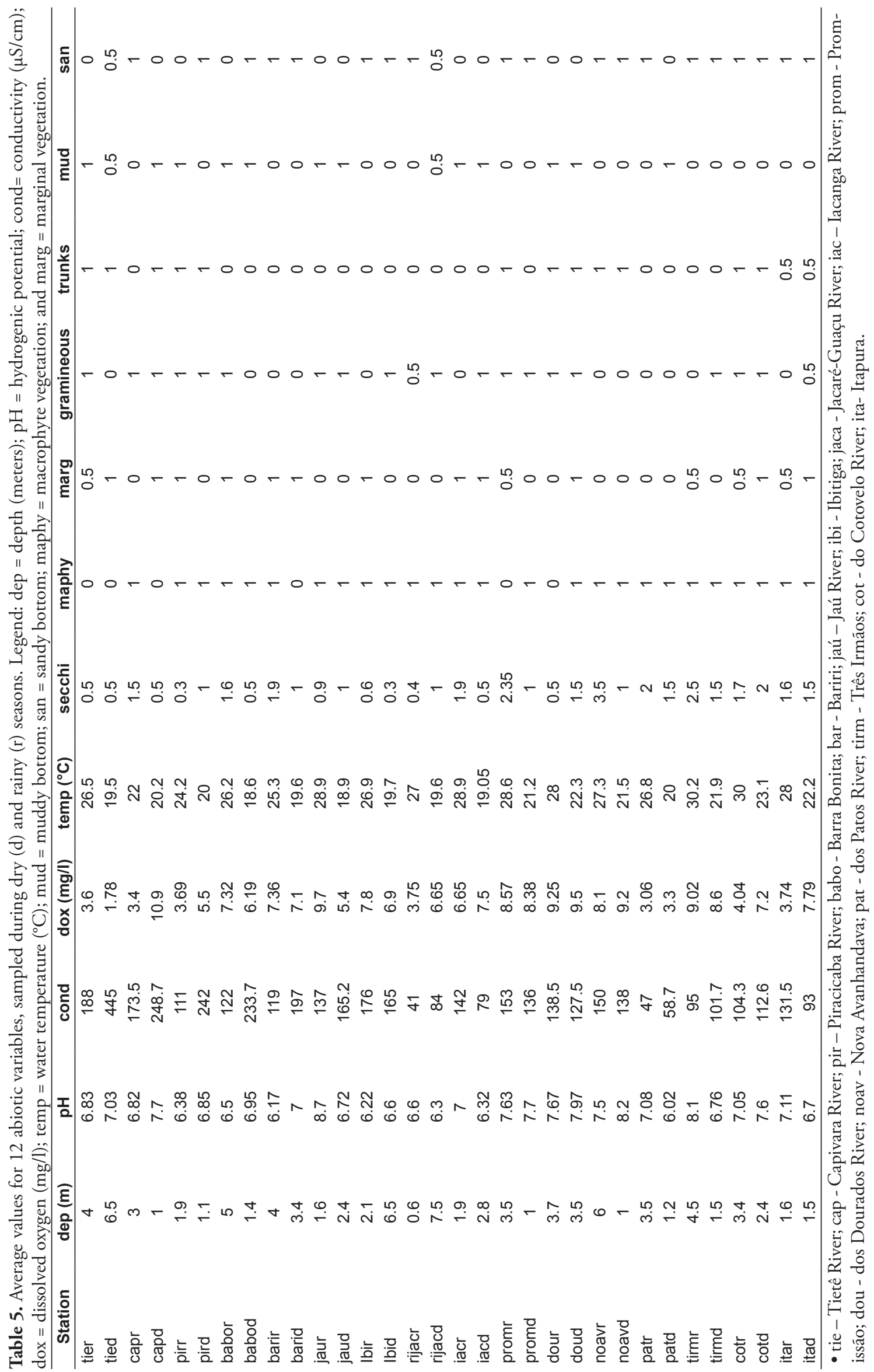


The Principal Components Analysis was performed with the data obtained. The aim was to simplify the information and identify the most important variables for habitat characterization in each sampling station. Only the first two components, which together explained 39.9\% of the total variance, were considered (Table 6).

The first principal component accounted for $22.9 \%$ of the total variance. The main variables that contributed to form this axis were: conductivity, presence of gramineous, and muddy bottom, with positive values; and water transparency, macrophytes, and sandy bottom, with negative values. This component can be interpreted as the type of environment (lentic or lotic). The environments characterized as lentics were the dams and the transition river-reservoir, and the ones characterized as lotics were the stations located in the river phase (tributaries). The second principal component represented $16.9 \%$ of the variance. The more representative variables were the $\mathrm{pH}$, dissolved oxygen, temperature, water transparency, and presence of trunks, all with positive values. This component was interpreted as the water quality of the sampling stations.

The analysis has also indicated inverse relationships between the variables conductivity, presence of gramineous and muddy bottom, and the variables transparency, presence of macrophytes and sandy bottom. In this way, the stations with higher conductivity had also more gramineous and muddy bottom. The opposite was as well verified.

Figure 3 shows the sampling stations arranged according to their scores. The stations characterized as lotics can be found on the right, and the ones

Table 6. Results from the Principal Component Analysis: values obtained for the abiotic variables of each principal component with the two greatest variance percentages.

\begin{tabular}{lrr}
\hline \multicolumn{1}{c}{ Abiotic variables } & PC1 & PC2 \\
\hline Depth & 0.087 & 0.144 \\
pH & 0.065 & $\mathbf{0 . 7 5 1}$ \\
Conductivity & $\mathbf{0 . 4 4 0}$ & 0.146 \\
Dissolved oxygen & 0.068 & $\mathbf{0 . 4 5 7}$ \\
Temperature & -0.247 & $\mathbf{0 . 5 5 3}$ \\
Water transparency (Secchi) & $\mathbf{- 0 . 5 4 5}$ & $\mathbf{0 . 5 3 8}$ \\
Macrophyte vegetation & $\mathbf{- 0 . 6 0 2}$ & -0.387 \\
Marginal vegetation & 0.302 & 0.301 \\
Gramineous & $\mathbf{0 . 4 6 9}$ & -0.072 \\
Trunks & $\mathbf{0 . 4 0 3}$ & $\mathbf{0 . 6 0 1}$ \\
Muddy bottom & $\mathbf{0 . 8 1 4}$ & -0.159 \\
Sandy bottom & $\mathbf{- 0 . 8 1 4}$ & 0.159 \\
Percentage of variance by factor & $\mathbf{2 2 . 8 \%}$ & $17.2 \%$ \\
Accumulated variance & & $39.9 \%$ \\
\hline
\end{tabular}

characterized as lentics on the left. The lotic stations presented muddy bottom, higher abundance of gramineous and floating macrophytes, and increased conductivity values; whilst the lentic stations presented high abundance of submerged macrophytes, sandy bottom, and high values for water transparency.

In the vertical line, it was verified that the stations placed in the lower part of the graphic had lower values for $\mathrm{pH}$, transparency, oxygen, and temperature, and had none or low density of trunks. The sampling stations placed in the upper part of the graphic presented high values for $\mathrm{pH}$, transparency, oxygen, and temperature, and presented high density of trunks, important microhabitats for aquatic organisms. There were, also, segregation between the best tributaries with better environmental conditions, as Dourado River (dou01), and the worst ones, as Jaú River (jau01) and Iacanga (iac01). A scheme of changes in habitat characteristics along Medium and Low Tietê River is given in Figure 4.

\section{Discussion}

The environmental characterization of this work indicated that seasonality influences water and sediment variables with clear differences between dry and rainy seasons. A number of recent studies performed in reservoirs have also pointed to seasonal differences in physical and chemical parameters in water and sediment (Pagioro et al., 2005; Vieira et al., 2005; Rodgher et al., 2005; Pinto-Coelho et al., 2006; Soares and Mozeto, 2006; Ribeiro-Filho et al., 2011).

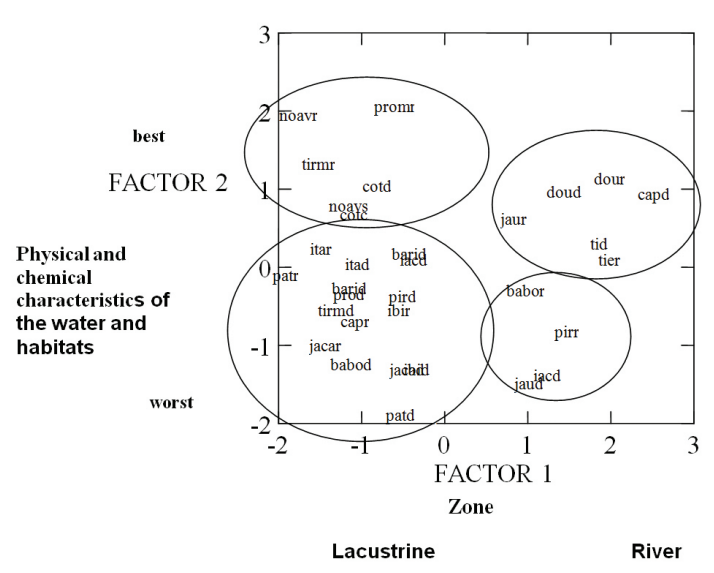

Figure 3. Diagram representing the types of environment and water quality for the sampling stations in Medium and Low Tietê River. 


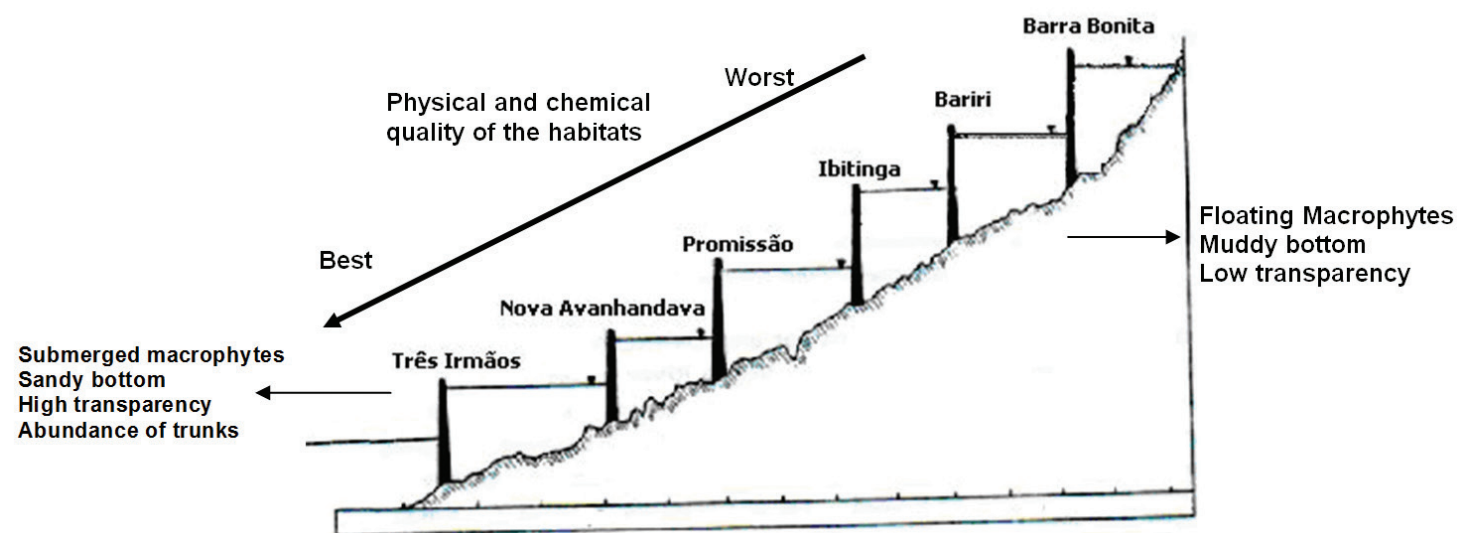

Figure 4. Gradient of habitats and water quality along the reservoirs cascade of the Medium and Low Tietê River stretches.

Water level fluctuation in reservoirs, due to operational procedures, has great influence on their physical, chemical and biological characteristics (Tundisi, 1996, 1999b). These characteristics are also regulated by seasonality. Thus, both factors (fluctuation and seasonality) are in great part responsible for the physical and chemical dynamics of water and sediment characteristics. According to Agostinho et al. (1999) total nitrogen, nitrate and turbidity did not display seasonal patterns.

In the reservoirs of Medium and Low Tietê River, high concentrations of suspended materials were verified in the rainy season. This was probably due to runoff. According to Pagioro et al. (2005), there is an increment of foreign material influx during the rainy season, which can be demonstrated by the variables of turbidity and total phosphorus. Considering another tropical reservoir, Sáo Simão (MG/GO), clear seasonality in relation to transparency, turbidity, and total suspended solids was as well identified (Pinto-Coelho et al., 2006).

Moreover, during the rainy season, transparency diminished and the turbidity increased; this is in agreement with the findings of the present work. Cavenaghi et al. (2003) revealed higher turbidity in the rainy season in five Tietê River reservoirs. Vieira et al. (2005) have also verified differences between the rainy and dry seasons for total suspended solids and conductivity in the Ibitinga reservoir. These authors emphasized that the quality, kind and origin of suspended solids in the water were greatly influenced by the climate, landscape and geology of the drainage basin as well as by human actions. Ribeiro-Filho $(2006,2008)$ and Ribeiro-Filho et al. (2011) pointed to rain as an important factor in relation to water transparency in the Itaipu Reservoir, with a negative correlation between both variables, and noted the importance of measuring these abiotic factors to estimate the productivity of aquatic systems.

High pluviosity contributes for the entry of organic and inorganic materials in the water bodies. The increase in the concentrations of nitrite, total phosphorus, total phosphate and inorganic phosphate, also in the rainy season, can be related to soil fertilization. This is carried out by farmers in crops, mostly sugar cane, placed on the edge of the reservoirs. In Ibitinga reservoir, agricultural activity was the hypothesis for the entry of limestone by means of surface drainage and lixiviating (Vieira et al., 2005). According to Fracácio et al. (2002), this situation is made worst by the lack of ciliar forest, which would retain a great part of the materials.

To Pagioro et al. (2005), water transparency increases in the direction of the dam due to sedimentation of solid particles. In the current work, a reduction in the values of suspended materials, nitrogen and phosphorus along the cascade of reservoirs was found. Barbosa et al. (1999) has also verified the same gradient in this study area: the values of total suspended organic and inorganic materials, turbidity, and phosphorus were reduced from Barra Bonita to Três Irmãos reservoir. Numerous studies have documented a reduction in the levels of phosphate, nitrogen, turbidity and solids along the Tietê river, finding higher values in Barra Bonita reservoir. Cavenaghi et al. (2003) reduction observed over the reservoirs for suspended solids, turbidity and conductivity. Roberto et al. 
(2009) observed an increase in transparency of the water downstream from Porto Primavera Dam and the highest values of water transparency observed in recent years in Itaipu Reservoir, may be due to the cascading effect caused by the Porto Primavera Dam.

Agostinho et al. (1999) said that a major part of the phosphorous concentration is retained in upstream reservoirs, in the basin of the rivers Grande, Tietê and Paranapanema. Studies accomplished by Nogueira et al. (2005) (Paranepanema River) and Roberto et al. (2009) (Paraná River) showed that there is a phosphorous decreasing in cascade reservoirs. The nutrient retention in upstream reservoirs has long been considered the main process, which inhibits the acceleration of eutrophication in reservoirs lower in the Upper Paraná River (Tundisi et al., 1993).

Tundisi et al. (1991) found a reduction of nitrate, phosphate and conductivity values, and an increase of the photic zone along of the cascade of reservoirs. This fact can be one reason for differences among the biological communities, such as zooplankton, macrophytes, and fishes identified along the river. This is due to its influence upon physical biological and chemical aspects such as: increase in predator's visual ability; higher food offer; and differences in conductivity, turbidity, phosphorus and nitrogen.

A clear distribution of ecological groups in Rosana reservoir, with the dominance of submerged species next to the dam and free floating species next to the mouth of Paranapanema River, has previously been verified (Thomaz et al., 2005). Considering chains of reservoirs, submerged species of macrophytes tend to be more concentrated downstream and floating species upstream (Thomaz and Bini, 1999). The existence of this gradient, i.e. a difference in limnological conditions in the reservoirs downstream from Ibitinga, occurs due to the retention of part of the nutrients (mainly nitrogen and phosphorus). Therefore, the reservoirs operate as nutrient accumulators, holding up the eutrophication process downstream (Tundisi, 1993).

In relation to the sediment also decreased along the reservoir cascade of parameters. The same conclusion reached Cavenaghi et al. (2003) stating that higher values were obtained for Barra Bonita, Bariri and Ibitinga reservoirs and lower values for Promissão and Nova Avanhandava. Concerning metals, high concentrations potentially bioavailable (or weakly bonded) were found, mainly for cadmium, iron, copper and manganese. The higher metal concentrations were detected in Tietê (before Barra Bonita) and Piracicaba rivers. These places are subjected to intense discharge of pollutants from different sources such as sewage, industrial effluents and pesticides. Moreover, a reduction in metal concentrations both in water and sediment along the cascade of reservoirs was found. The values decreased especially for iron, manganese and zinc, reflecting a reduction in the entry of these metals along the cascade. However, the same effect was not observed for cadmium and chrome, which increased along the cascade, indicating the presence of diffuse sources of pollution in the last reservoirs.

The Principal Component Analysis has shown, in a way, what happens along the cascade. It was possible to identify differences between the sampling stations along the river: upstream stations showed, generally, higher values of conductivity, hardness, nitrite, ammonia, phosphate, and chlorophyll, and lower values of dissolved oxygen and water transparency, which shows they are places that receive heavy load of effluents from diffuse and punctual pollution. Downstream are placed the stations with the lower values of conductivity, hardness, nitrite, ammonia, phosphate, and chlorophyll, and higher values of dissolved oxygen and water transparency, presenting better conditions than the ones placed upstream. This fact can be explained by the reduction in the entry of effluents, as well as the action of the reservoirs, which work as chemostats, keeping part of the pollutants.

In the present work, the variables related to habitat showed segregation between the sampling stations located in the reservoirs and tributaries concerning abiotic characteristics. The stations placed in the tributaries showed lower values of dissolved oxygen, $\mathrm{pH}$ and water transparency, and the opposite was found for the ones placed in the reservoirs. According to Pinto-Coelho et al. (2006), the tributaries present higher values of turbidity when compared to São Simão reservoir. This pattern can explain the low transparency of the tributaries as a consequence of the total solids transported by them to the reservoirs. Cavenaghi et al. (2003) obtained similar results on the same system, stressing that tributaries have higher values of turbidity and suspended solids and lower Secchi. The reservoirs located upstream from Promissão (Barra Bonita,Bariri and Ibitinga) present lower values of dissolved oxygen, $\mathrm{pH}$, and transparency when compared to the ones downstream (Promissão, Nova Avanhandava and Três Irmãos). These results also suggest the existence of a gradient along the 
reservoirs cascade: the reservoirs placed upstream have higher alterations in the limnological variables than the ones placed downstream. The first reservoirs receive the greater part of the pollutants, since they are located in more heavily populated and industrialized areas. As mentioned before, they decant part of the pollutants. Cavenaghi et al. (2003) said the $\mathrm{pH}$ is lower at the beginning of the cascade going to 8.0 at the end, which reinforces found and discussed by this study.

The analysis of the abiotic variables related to habitat indicated differences between the sampling stations. Such differences can be used as indicators of impacts, as well as explain the structure of fish community in these places. The tributaries and the Barra Bonita, Bariri and Ibitinga reservoirs have a physical habitat formed basically by emerging macrophytes, while Tietê, Piracicaba, and Dourado rivers and Promissão reservoir were markedly more influenced by the presence of trunks and rocks.

The sampling stations which presented macrophytes can be divided in two groups: the ones with predominant floating macrophytes, such as some of the tributaries and Barra Bonita, Bariri, and Ibitinga reservoirs; and the stations with predominant submerged macrophytes, as Nova Anhandava and Três Irmãos reservoirs. In the stations with lower concentrations of nutrients and higher water transparency, the submerged macrophytes (e.g. Egeria sp. - Elodea) predominated; whereas in the stations with greater concentration of nutrients and low water transparency more floating macrophytes occurred like Eichhornia $s p$. (water hyacinth), Salvinia sp. and Pistia sp. (water lettuce). Thomaz (2005) and Thomaz et al. (2005) had similar results, and also indicated that no submerged species was found in Barra Bonita whilst the ten more abundant species in Jupiá reservoir were submerged. Besides, Cavenaghi et al. (2003) found that greater light penetration in the water column is related to the higher occurrence of aquatic plants emerged, such as those cited. These authors found this result in Promissão and Nova Avanhandava reservoirs. Thomaz and Bini (1999) presented a hypothetical tendency for aquatic macrophytes assembly structures. This shows that the growth of submerged macrophytes in oligotrophic or mesotrophic ecosystems is due to the high water transparency, lack of zooplanktivore fishes, or mechanisms directly related to submerged macrophytes, as reduction of water circulation.

Concerning data on habitats, the Principal Component Analysis also indicated the importance of the bottom type in the sampling stations, which can be divided into two groups: the muddy bottom stations (tributaries) and the sandy bottom stations (Promissão, Nova Avanhandava, and Três Irmãos). The type of bottom can be associated with the higher or lower entrance of sediment and organic matter into the system, which will be retained in the first reservoirs by sedimentation. These materials come from the tributaries or Tietê and Piracicaba rivers, constituents of Barra Bonita reservoir, as well as from soil washing and by the lack of ciliar vegetation. The presence of marginal and floating plants is associated with the sedimentation process occurs in the margins and in areas of the tributaries entering the reservoir. Areas of intense sedimentation favors the occurrence of macrophytes, especially floating, as they reach the bottom (Cavenaghi et al., 2003). The bottom type is a determinant factor because it can influence the biological community abundance mostly in relation to diet.

Therefore, modifications were identified in the habitats general structure along the medium Tietê stretch: emerging macrophytes and muddy bottom predominate upstream; and submerging macrophytes and sandy bottom predominate downstream. The water characteristics should be taken into consideration, because they reflect the impacts upon the drainage basin of each reservoir.

\section{Acknowledgements}

This work was supported by funds provided by FAPESP (99/12112-9) and PRONEX/FINEP/ CNPq and PROBIO (MMA/BIRD/GEF). We also tank the technicians involved in the laboratory and in the fieldwork and the anonymous reviewers for their valuable corrections.

\section{References}

AGOSTINHO, AA., MIRANDA, LE., BINI, LM., GOMES, LC., THOMAS, SM. and SUZUKI, HI. 1999. Patterns of colonization in neotropical reservoirs, and prognoses on aging. In TUNDISI, JG. and STRAŠKRABA, M., ed. Theorical reservoir ecology and its application. Leiden: Backhuys Publishers. p. 227-265.

American Public Health Association - APHA. 1995. Standard methods for the examination of water and wastewater. 19th ed. Washington.

Associação Brasileira de Normas Técnicas - ABNT. 1968. Análise granulométrica de solos. Rio de Janeiro. 7 p. (Método Brasileiro, no. 32).

BARBOSA, FAR., PADISÁK, J., ESPÍNDOLA, ELG., BORICS, G. and ROCHA, O. 1999. The cascading reservoir continuum concept (CRCC) and its application to the River Tietê-basin, São Paulo State, 
Brazil. In TUNDISI, JG. and STRAŠKRABA, M., ed. Theorical reservoir ecology and its application. Leiden: Backhuys Publishers. p. 425-437.

CALLISTO, M., GOULART, M., BARBOSA, FAR. and ROCHA, O. 2005. Biodiversity assesment of benthic macroinvertebrates along a reservoir cascade in the lower São Francisco River (Northeastern Brazil). Brazilian Journal of Biology, vol. 65, no. 2, p. 229240. PMid:16097725. http://dx.doi.org/10.1590/ S1519-69842005000200006

CAVENAGHI, AL., VELINI, ED., GALO, MLBT., CARVALHO, FT., NEGRISOLI, E., TRINDADE, MLB. and SIMIONATO, JLA. 2003. Caracterização da qualidade de água e sedimento relacionados com a ocorrência de plantas aquáticas em cinco reservatórios da Bacia do Rio Tietê. Planta Daninha, vol. 21, no. spe, p. 43-52.

COOKE, GD., WELCH, EB. and PETERSON, SA. 1993. Restoration and management of lakes and reservoirs. 2th ed. Boca Raton: Lewis Publishers. p. 21-43.

DIGBY, PGN. and KEMPTON, RA. 1987. Multivariate analysis of ecological communities. London: Chapman \& Hall. 206 p.

FANG, YP. and DENG, W. 2011. The critical scale and section management of cascade hydropower exploitation in Southwestern China. Energy, vol. 36, no. 10, p. 5944-5953. http://dx.doi.org/10.1016/j. energy.2011.08.022

FELISBERTO, SA. and RODRIGUES, L. 2005. Periphytic community of reseroirs cascade in the Parapanema river, Brazil. Acta Scientiarum: Biological Sciences, vol. 27, no. 3, p. 215-233.

FONSECA, AL. 1997. Avaliação da qualidade da água do rio Piracicaba, SP, através de testes de toxicidade com invertebrados. São Carlos: Universidade de São Paulo. 211 p. [Tese de Doutorado].

FRACÁCIO, R., ESPÍNDOLA, ELG., RODGHER, S., PEREIRA, RHG., ROCHA, O. and VERANI, NF. 2002. Limnologia dos reservatórios em cascata do Médio e Baixo Rio Tietê: uma análise espacial e temporal. In Universidade de São Paulo - USP, Programa de Pós-graduação em Ciências da Engenharia Ambiental, org. Recursos hidroenergéticos: usos, impactos e planejamento integrado. São Carlos: Rima. p. 145-163.

GOLTERMAN, HL., CLYMO, RS. and OHNSTAD, R. 1978. Methods for physical and chemical analysis of freshwater. 2th ed. Oxford: Blackweel Scientific Publications. (International Biological Programme Handbook, no. 8).

GORDON, E. and MEENTEMEYER, RK. 2006. Effects of dam operation and land use on stream channel morphology and riparian vegetation. Geomorphology, vol. 82, no. 3, p. 412-429. http:// dx.doi.org/10.1016/j.geomorph.2006.06.001
JORCIN, A. and NOGUEIRA, MG. 2008. Benthic macroinvertebrates in the Paranapanema reservoir cascade (southeast Brazil). Brazilian Journal of Biology, vol. 68, no. 4, p. 1013-1024. PMid:19197472. http:// dx.doi.org/10.1590/S1519-69842008000500009

KOROLEFF, F. 1976. Determination of nutrients. In GRASSOHOF, K., ed. Methods of seawater analysis. New York: Verlag Chemie Weinhein. p. 117-118.

LLOYD, R. 1992. Pollution and freshwater fish. Oxford: Fishing News Books. 176 p.

LI, J., DONG, S., YANG, Z., PENG, M., LIU, S. and LI, X. 2012. Effects of cascade hydropower dams on the structure and distribution of riparian and upland vegetation along the middle-lower LancangMekong River. Forest Ecology and Management, vol. 284, p. 251-259. http://dx.doi.org/10.1016/j. foreco.2012.07.050

MACKERETH, FJH., HERON, J. and TALLING, JF. 1978. Water analysis: some revised methods for limnologists. Kendal: Titus Wilson \& Son Printers. (Freshwater Biological Association Scientific Publication, no. 36).

MALLIK, AU. and RICHARDSON, JS. 2009. Riparian vegetation change in upstream and downstream reaches of three temperate rivers dammed for hydroelectric generation in British Columbia, Canada. Ecological Engineering, vol. 35, no. 5, p. 810-819. http://dx.doi.org/10.1016/j. ecoleng.2008.12.005

MANLY, BJ. 1986. Multivariate statistical methods: a primer. London: Chapman \& Hall. 281 p.

NILSSON, C., REIDY, CA., DYNESIUS, M. and REVENGA, C. 2005. Fragmentation and flow regulation of the world's large river systems. Science, vol. 308, no. 5720 p. 405-408. http://dx.doi. org/10.1126/science.1107887

NOGUEIRA, MG., JORCIN, A., VIANNA, NC. and DE BRITTO, YCT. 2005. Reservatório em cascata e os efeitos na limnologia e organização das comunidades bióticas (fitoplâncton, zooplâncton e zoobentos): um estudo de caso no rio Paranapanema (SP/PR). In NOGUEIRA, MG., HENRY, R. and JORCIN, A., eds. Ecologia de reservatórios. São Carlos: Rima.

NOGUEIRA, MG., FERRAREZE, M., MOREIRA, ML. and GOUÊA, RM. 2010. Phytoplankton assemblages in a reservoir cascade of a large tropical-subtropical river (SE, Brazil). Brazilian Journal of Biology, vol. 70, no. 3, p. 781-793. PMid:21085783. http://dx.doi.org/10.1590/S151969842010000400009

NUSH, EA. 1980. Comparation of different methods for chlorophyll and phaeopigments determination. Archiv für Hydrobiologie, vol. 14, no. 1, p. 14-36.

OUYANG, W., HAO, F., SONG, K. and ZHANG, X. 2011. Cascade Dam-Induced Hydrological Disturbance and Environmental Impact in the 
Upper Stream of the Yellow River. Water Resour Manage, vol. 25, no. 3, p. 913-927. http://dx.doi. org/10.1007/s11269-010-9733-6

PADISÁK, J., BABOSA, FAR., BORBÉLY, G., BORICS, G., CHORUS, I., ESPÍNDOLA, ELG., HEINZE, R., ROCHA, O., TÖRÖKNÉ, AK. and VASAS, G. 2000. Phytoplankton composition, biodiversity and pilot survey of toxic Cyanoprokaryotes in a large cascadian reservoir system (Tietê basin, Brazil). Verhandlungen des Internationalen Verein Limnologie, vol. 27, p. 2734-2742.

PAGIORO, TA., ROBERTO, MC., THOMAZ, SM., PIERINI, SA. and TAKA, M. 2005. Zonação longitudinal das variáveis limnológicas abióticas em reservatórios. In RODRIGUES, L., THOMAZ, SM., AGOSTINHO, AA. and GOMES, LC., org. Biocenoses em reservatórios: padrōes espaciais e temporais. São Carlos: RIMA. p. 39-46.

PATESSE, ML., PETRERE JÚNIOR, M. and SPINGOLON, RJ. 2007. The hydraulic management of the Barra Bonita reservoir (SP, Brazil) as a factor influencing the temporal succession of its fish community. Brazilian Journal of Biology, vol. 67, no. 3, p. 433-445. PMid:18094826. http://dx.doi. org/10.1590/S1519-69842007000300008

PINTO-COELHO, RM., AZEVEDO, LMA., RIZZI, PEV., BEZERRA-NETO, JF. and ROLLA, ME. 2006. Origens e efeitos do aporte de nutrientes em um reservatório tropical de grande porte: reservatório de São Simão (MG/GO). In NOGUEIRA, MG., HENRY, R. and JORCIN, A. Ecologia de reservatórios: impactos potenciais, açóes de manejo e sistemas em cascata. São Carlos: Rima. p. 127-164.

PLATTS, WS., ARMOUR, C., BOOTH, GD., BRYANT, M., BUFFORD, JL., CUPLIN, P., JENSEN, S., LIENKAEMPER, GW., MINSHALL, GW., MONSEN, SP., NELSON, RL., SEDELL, JR. and TUHY, JS. 1987. Methods for evaluating riparian habitats with applications to management. Ogden: USDA Forest Service. 177 p. (General Technical Report INT-221).

RIBEIRO-FILHO, RA., PETRERE JUNIOR, M., BENASSI, SF. and PEREIRA, JMA. 2011. Itaipu Reservoir limnology: eutrophication degree and the horizontal distribution of its limnological variables. Brazilian Journal of Biology, vol. 71, no. 4, p. 889902.

RIBEIRO-FILHO, RA. 2006. Relaçōes tróficas e limnológicas no reservatório de Itaipu: uma análise do impacto da biomassa pesqueira nas comunidades planctônicas. São Carlos: Universidade de São Paulo. 139 p. [Tese de Doutorado em Ciências da Engenharia Ambiental].

RIBEIRO-FILHO, RA. 2008. Evolução histórica das relaçôes tróficas e limnológicas no reservatório de Itaipu: efeitos top-down e bottom-up na produção pesqueira. Rio Claro: UNESP. 102 p. (Relatório final).
ROBERTO, MC., SANTANA, NF. and THOMAZ, SM. 2009. Limnology in the Upper Paraná River floodplain. Brazilian Journal of Biology, vol. 69, no. 2, p. 717-725 PMid:19738977. http://dx.doi. org/10.1590/S1519-69842009000300025

RODGHER, S., ESPÍNDOLA, ELG., ROCHA, O., FRACÁCIO, R., PEREIRA, RHG. and RODRIGUES, MHS. 2005. Limnological and Ecotoxicological Studies In the Cascade of Reservoirs in the Tietê River (Sáo Paulo, Brazil). Brazilian Journal of Biology, vol. 65, no. 4, p. 697-710. PMid:16532194. http://dx.doi.org/10.1590/S151969842005000400017

SILVA, CA., TRAIN, S. and RODRIGUES, LC. 2005. Phytoplankton assemblages in a Brazilian subtropical cascading reservoir system. Hydrobiologia, vol. 537, no. 1-3, p. 99-109. http://dx.doi.org/10.1007/ s10750-004-2552-0

SOARES, A. and MOZETO, AA. 2006. Water Quality in the Tietê River Reservoirs (Billings, Barra Bonita, Bariri e Promissão, SP- Brazil) and nutrient fluxes across the sediment-water interface (Barra Bonita). Acta Limnologica Brasiliensia, vol. 18, no. 3, p. 247266.

SMITH, WS. 2004. A importância dos tributários, a influência da fragmentação artificial de rios e da introdução de espécies exóticas na comunidade de peixes dos reservatórios do Médio e Baixo Tietê. São Carlos: Universidade de Sáo Paulo. 296 p. [Tese de Doutorado em Ciências da Engenharia Ambiental].

STRAŠKRABA, M. 1994. Vltava cascade as teaching grounds for reservoir limnology. Water Science \& Technology, vol. 30, no. 10, p. 289-297.

TEALDI, S., CAMPOREALE, C. and RIDOLFI, L. 2011. Modeling the impact of river damming on riparian vegetation. Journal of Hydrology, vol. 396, no. 3, p. 302-312. http://dx.doi.org/10.1016/j. jhydrol.2010.11.016

TEIXEIRA, C., TUNDISI, JG. and KUTNER, MB. 1978. Plankton studies in magrove environmental. II. The standing stock and some ecological factors. Boletim do Instituto Oceanográfico, vol. 24, p. 23-41.

TESSIER, A. and CAMPBELL, PGC. 1987. Partitioning of trace metals in sediments: Relationships with bioavailability. Hydrobiologia, vol. 149, no. 1, p. 4352. http://dx.doi.org/10.1007/BF00048645

THOMAZ, SM. 2005. Fatores que afetam a distribuição e o desenvolvimento de macrófitas aquáticas em reservatórios: uma análise em diferentes escalas. In NOGUEIRA, MG., HENRY, R. and JORCIN, A. Ecologia de reservatórios: impactos potenciais, ações de manejo e sistemas em cascata. São Carlos: Rima. p. 165-181.

THOMAZ, SM. and BINI, LM. 1999. A expansão das macrófitas aquáticas e implicações para o manejo 
de reservatórios: um estudo na represa de Itaipu. In HENRY, R., ed. Ecologia de reservatório: estrutura, função e aspectos sociais. Botucatu: FUNBIO/ FAPESP. p. 599-625.

THOMAZ, SM., PAGIORO, TA., BINI, LM. and ROBERTO, MC. 2005. Ocorrência e distribuição de macrófitas aquáticas em reservatórios. In RODRIGUES, L., THOMAZ, SM., AGOSTINHO, AA. and GOMES, LC., org. Biocenoses em reservatórios: padróes espaciais e temporais. São Carlos: RIMA. p. 39-46.

TUNDISI, JG., MATSUMURA-TUNDISI, T., CALIJURI, MC. and NOVO, EML. 1991. Comparative limnology of five reservoirs in the middle Tietê River, São Paulo State. Verhandlungen International Verein Limnology, vol. 24, no. 5, p. 1489-1496.

TUNDISI, JG. 1993. Represas do Paraná superior: limnologia e bases científicas para o gerenciamento. In BOLTOVSKOY, A. and LOPEZ, HL., eds. Conferências de Limnologia. La Plata: Instituto de Limnologia “Dr. Raúl A. Ringuelet.”. p. 41-52.
TUNDISI, JG., MATSUMURA-TUNDISI, T. and CALIJURI, MC. 1993. Limnology and management of reservoirs in Brazil. In STRAŠKRABA, M., TUNDISI, JG. and DUNCAN, A., eds. Comparative reservoir limnology and water quality management. Dordrecht: Kluwer Academic. p. 25-55.

TUNDISI, JG. 1996. Reservoir as complex systems. Ciência e Cultura, vol. 48, no. 5-6, p. 383-87.

TUNDISI, JG. 1999a. Theorical basis for reservoir management. In REBOUÇAS, AC., BRAGA, B. and TUNDISI, JG. Águas doces no Brasil: capital ecológico, uso e conservação. São Paulo: Escrituras. p. 153-194. (Cap. 5).

TUNDISI, JG. 1999b. Reservatórios como sistemas complexos: teoria, aplicaçóes e perspectivas para usos múltiplos. In HENRY, R., ed. Ecologia de reservatórios. Botucatu: FUNDIBIO/FAPESP. p. 19-38.

VIEIRA, MS., MOURA, MAM. and FERREIRA, JR. 2005. Estudo das variaçóes sazonais e espaciais dos íons dominantes na água e no sedimento da represa de Ibitinga (São Paulo, Brasil-21\%45'S e $\left.48^{\circ} 50^{\prime} \mathrm{W}\right)$. Arquivos do Instituto Biológico, vol. 72, no. 4, p. 523-534.

Received: 14 November 2013 Accepted: 22 May 2014 